\title{
RN
}

\section{The Academic Master's Program in Management: is it relevant to professional practice?}

\author{
Victor Meyer Jr., Priscilla Veiga Bueno² \\ ${ }^{1}$ Pontifícia Universidade Católica do Paraná - victormeyerir@gmail.com \\ ${ }^{2}$ Faculdade Educacional de Colombo - priscillabueno@yahoo.com.br
}

\section{KEYWORDS}

Academic Master's Program,

Management,

Academic,

Social,

Institutional Dimensions,

Professional Practice.

Received 27.02.2019

Reviewed 24.04.2019

Accepted 19.06.2019

ISSN 1980-4431

Double blind review

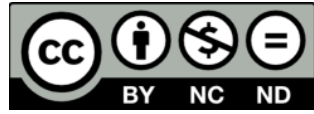

ABSTRACT

This is an analysis of the relevance of an academic Master's Program in Management to professional practice from the viewpoint of graduates and professors. The study was guided by three perspectives: "academic", "social” and "institutional". It is a descriptive study, focusing on the case of an academic program offered by a Brazilian private university. In the academic dimension, the analysis revealed its emphasis on traditional teaching methods in relation to professional and vocational aspects. A weak social identity and the inexistence of exchanges of experiences, and no perception of a common technical language were highlighted in the social dimension. The prestige of the university, rather than the program, was the main factor that influenced institutional attractiveness, albeit with no benefits in terms of employability. The conclusions show a need to reevaluate the current content and teaching methods to integrate the degree better into management and professional practice to bridge these gaps. This article contributes to the field by identifying critical points of the degree program that require a better alignment of capability, knowledge and resources with the expectations and demands of the productive sector and society. Studies in this field in Brazil are scarce and there is little empirical evidence of the influence of management education on professional activities and organizational management.

\section{PALAVRAS-CHAVE}

Mestrado acadêmico, Administração, Dimensões acadêmica, Social e institucional, Prática profissional.

\section{RESUMO}

Neste trabalho é analisada a relevância de um curso de mestrado acadêmico em administração para a prática profissional, na perspectiva dos seus egressos e professores. $\mathrm{O}$ estudo fundamentou em três dimensões: acadêmica, social e institucional. Trata-se de um trabalho descritivo com foco em estudo de caso de um curso de mestrado acadêmico ofertado por uma universidade privada brasileira. Na dimensão acadêmica, a análise revelou a existência de uma ênfase em métodos tradicionais de ensino no que se refere aos aspectos de formação profissional e vocacional. Observou-se, na dimensão social, uma fraca identidade e a inexistência de trocas de experiências sendo despercebida a disseminação de uma linguagem técnica comum. Mais do que o prestigio do curso foi o prestigio da universidade que foi considerado um fator influente na atração à instituição, embora sem produzir impacto na empregabilidade. As conclusões indicam a necessidade de uma reavaliação do atual conteúdo e metodologias de ensino, como forma de melhor integrar o conteúdo do mestrado com a administração e prática profissional, preenchendo um hiato existente. Este trabalho contribui para o campo de conhecimento ao identificar pontos críticos do curso o qual requer um melhor alinhamento da capacidade, conhecimento e recursos existentes com as expectativas e demandas do setor produtivo e sociedade. Estudos neste campo no Brasil são escassos, havendo poucas evidencias empíricas da influência da educação em administração nas atividades profissionais e na administração organizacional. 


\section{Introduction}

Higher education makes an important contribution to the formation and development of the intellectual capacity of individuals seeking to improve society. Universities are social institutions that play a fundamental role in preparing qualified professionals for the productive sector, the production of basic and applied knowledge for scientific and technological development and setting people on the path to citizenship.

Universities have traditionally played two essential setting people on the path to citizenship.

Universities have traditionally played two essential roles. The first is to prepare professionals in a wide range of fields of knowledge. The second is the critical function of thinking about society and proposing solutions to its problems and helping to transform it.

Traditional studies in the field of higher education have pointed out that the academic sector is the core area where education takes place. This is the locus where the functions of teaching, research and services, essential to the fulfilment of the institutional mission, are carried out (Peterson et al., 1997; Birnbaum, 1989; Gumport 2007 and Bastedo 2012). Universities are identified as social entities in which professors, students and managers interact and build a community where teaching, learning and advancement of knowledge occur (Peterson et al., 1997; Gumport, 2000; Bastedo, 2012, Caplan, 2018). As institutions, universities are the main providers of relevant educational services to society, meeting the expectations of their stakeholders. From this perspective, their institutional effectiveness depends on the quality and relevance of their educational services being perceived as relevant, prestigious and legitimate in the eyes of society (Meyer and Rowan, 1978; Scott, 1995, Meyer and Murphy, 2003; Caplan, 2018).

Furthermore, various levels of learning have been constituted at universities, from undergraduate programs to stricto sensu or graduate programs. In Brazil, the performance of this kind of program is supervised by the Ministry of Education, and evaluated at the graduate level by a specific agency, the Coordination for the Improvement of Higher Education Personnel (CAPES). Its task is to supervise and promote the development of graduate programs, assess the quality and importance of their achievements, and organize a ranking of this type of program in the country.

The growth and quality of the graduate system in Brazil have raised awareness among those involved, focusing on stricto sensu programs as an instrument for the economic, scientific and technological development of the country. Guided by this principle, Academic Master's Degree programs in management, which first appeared in 1967, have grown in number and importance, strengthening their formal role in qualifying professionals for the market and developing research studies in this field.

Over the last twenty years, we have seen in Brazil a rapid expansion and growth in the number of graduate programs in management, both stricto sensu (Master's Degrees and Doctorates) and MBAs, plus other lato sensu or certificate programs, whose purpose is essentially to provide managers with professional training. This industry of management has been analyzed in the United States and United Kingdom, and Business Schools have been the focus of reflective and critical studies (Pfeffer and Fong, 2002; Grey, 2004; Mintzberg, 2004; Bennis and O'Toole, 2005; Jarzabkowski et al., 2013).

In the last decade, we have witnessed a growing debate on management education and its effective contribution to professional practice in the field, with its advocates and critics taking a stance on the value and relevance of these Master's Degree programs. In Brazil, however, studies on this topic remain scarce, with little empirical evidence on the real benefits of training professional managers (Paixão and Souza, 2018), particularly in Academic Master's Programs at both public and private institutions.

In this article, we set out to examine the importance and contribution of a Brazilian Master's Degree Program in management to professional practice from the perspective of its graduates, and the reaction of faculty members regarding about these students' perspectives. In this study, we gathered evidence to examine the actual role of a well ranked academic Master's Degree program and contribute to the debate on management education.

\section{Management programs and their critics}


Management plays a very important role, making a decisive contribution to the workings of organizations and society in economic, social, technical, political and ethical terms. It is impossible to imagine society functioning without efficient, ethical, effective, reliable and, consequently, well managed organizations achieving their goals. Thus, management education is of great importance to society.

Since the nineteen nineties, Brazil has seen a growth in the number of management programs, especially Master's Degrees. This expansion is in keeping with the economic development of the country and has followed a trend already seen in the United States and United Kingdom, where business schools have been operational for over a century. Regarding the growing number of graduate programs in Brazil, we may highlight the creation of professional Master's Degree programs in management over the last twenty years. Simultaneously, there has been a growth in the number of post-graduate programs known as MBAs for marketing purposes.

In the Brazilian context, these MBA programs are known for their short-term, narrow scope, practical orientation toward professional management education and as certificate providers. These programs have been consolidated as highly successful products for their institutions, as shortterm graduate programs capable of boosting careers and providing alternatives for training in leadership (Wood Jr. and Cruz, 2014).

In the debate over the relevance of management education, critics have concentrated on aspects such as teaching, curriculum, skills and individual and professional benefits in the work market, focusing on traditional programs in business administration (MBAs) worldwide. Two opposing stances have been taken in this debate. The first emphasizes the importance of these courses, highlighting their contribution not only to preparing more competent and, therefore, better managers, but also to improving administrative practices and managerial skills to handle problems that arise in business (Elmuti, 2004; Davila, 2012; Jarzabkowski et al., 2013).

The second stance expresses a different point of view, questioning the teaching of management by highlighting a gap between the techniques and tools taught in MBA programs and the reality of the business world, the market and professional practices, thus challenging the current management education model. One of the most severe criticisms is that management is an essentially practical activity that cannot be taught in a classroom (Pfeffer and Fong, 2002; Grey, 2004; Mintzberg, 2004; Bennis and O'Toole, 2005; Ghoshal, 2005; Podolny, 2009).

Critics who hold this point of view claim that management is not a science, let alone a profession. It is a mixture of art, experience and technique (Mintzberg, 2004). Without experience, there is no art and no application of techniques. This criticism ranges from the selection of students to the teaching and pedagogical approach used in MBA programs, which have proved to be deficient with regard to the main goal of this kind of program: to prepare managers to work in the management of organizations (Grey, 2004).

To Mintzberg (2004), MBAs essentially concentrate on teaching analytical skills, with dysfunctional consequences for practical management. According to Bennis and O'Toole (2005), Master's Degrees in management do not impart useful skills; nor do they create leaders or inculcate ethical behavior - elements considered essential when preparing a professional for the market and competent and successful professional practice.

Therefore, criticism is focused on the program's academic structure and, particularly, its curriculum. The true cause of the crisis in education at business schools, according to Podolny (2009), is that the curriculum is almost entirely focused on the rigors of scientific research, in detriment of teaching relevant concepts, techniques and tools for professional life.

As MBA programs focus excessively on "scientific" research, administrators tend to hire professors who are researchers, with limited professional experience in management. The result is theoretical classes that are far from actual managerial practice and students who are not prepared to address concrete complex issues that are often immeasurable. In other words, they are not prepared for the practical requirements of management in the reality of organizations (Bennis and O'Toole, 2005). In this respect, management involves theories and approaches that are not morally neutral. According to Ghoshal (2005), 
many of these are destroying good managerial practice instead of aiding it.

Thus, traditional MBAs, with their curricula, textbooks, articles, disciplines and case methods, provide a type of teaching under which students cease to develop relevant practical knowledge and skills, creating a false impression of what management really means. The result is a professional qualification that, when put into practice, ends up undermining organizations and society. Using the classroom to help develop people who already work in management is an excellent idea, but attempting to make managers out of people who have never managed anything is nothing but an illusion (Mintzberg, 2004; Gosling and Mintzberg, 2006).

Bennis and O'Toole (2005) stress that although part of the research produced is of high quality, little of it is based on the reality of management in a business environment. The scientific model adopted by business schools, particularly in MBA programs, is based on a false premise that management is an academic subject like chemistry or geology, rather than a profession, such as medicine or law. Business schools and MBA programs have lost their way, and to find their way back, they need to act like traditional schools that prepare professionals for the real world.

Like other professional fields, graduation in management requires contributions from a number of academic subjects. In management, this contribution comes from the fields such as mathematics, economics, philosophy, anthropology and sociology. It is essential to distinguish between academic subjects and the profession. No curricular reform will be successful until the scientific and rational model is exchanged for a more adequate model built on the requirements of professional practice (Mintzberg 2004; Gosling and Mintzberg, 2006; Grey, 2009).

The socialization that results from MBA programs is another relevant factor when analyzing these programs (Datar et al., 2010). Management education plays a social role in providing an environment for learning and interaction between students and professors. In this process, students bring their individual experience of life, the world, organizations and society into the classroom.

Interaction between students and professors, in and out of the classroom, whether formal or informal, influences their cognition, behavior, values and sensemaking with regard to practice in organizational management. Informal networks are created by individuals with diverse goals concerning studies, the relevance of teaching and learning, the sharing of knowledge and the work market. Leavitt (1991) highlights that socialization in MBAs means sharing ways of thinking, value systems, interpersonal relationships and citizenship. Datar et al. (2010) are critical of these programs, stressing the excessive dissemination of a trade school mentality by business schools and the need to set limits on managerial models and markets.

To Grey (2009), MBA programs inculcate a clear symbolic indicator that favors certain types of knowledge and behavior lacking necessary concrete knowledge and skills, not only for professional practice but also for life in society. For this reason, professional and personal intellectual training for students deserves special attention in courses that focus on management education.

In practice, what we see is an environment where a socialization process is at work, with individuals acquiring only a more functional and less critical view of what occurs in the world of business management (Grey, 2009). One point that deserves to be highlighted is the language that is disseminated in MBA programs, represented by models, technical approaches and the use of metaphors. This leads to discourse and rhetoric that are characteristic of MBAs and are widely disseminated among their graduates, creating and shaping their own reality.

Collins (1979) and Berg (2003) draw attention to a discrepancy between the behavior of the market and its requirements in terms of formal education. This discrepancy is characteristic of a credentialist society, where a certain kind of formal education is required for a job, but this education is not actually put to use at work. This is the case of professional activities in the public sector, teaching at higher learning institutions and consultancy work. Educational credentials are more important in terms of employability than actual professional skills.

Looking at the Brazilian context of management schools, Wood, Jr., and Cruz (2014) note that the reconstruction of a new culture would 
depend on certifying organizations being capable of assimilating ideas, generating articles and incorporating criteria that influence the behavior of business schools. It is our understanding that this would also depend on the position and policies of regulating agencies, such as the CAPES, and the innovative and creative capacity of professors who, individually and with some restrictions, would alter the content and methods used in their disciplines and programs.

More recently, the debate on the importance of education in management has required an indepth and systematic analysis focusing on the relevance of studies in management being put into practice. Professional education, especially at the Master's Degree level, in management has proved to be a significant career investment, with high direct and indirect costs for users. More recently, in Brazil, this debate has become increasingly important, and it is imperative that new studies examining the relevance of Academic Master's Degrees in management, and particularly their training for professional practice, be conducted to further this debate.

\section{Method}

We adopted a multimethod research characterized as case study design based on questionnaires, interviews and participant observation (Eisenhardt, 1989; Stake, 1994; Creswell, 2017). The intention was to analyze the relevance of an academic Master's Program in Management to professional practice from the viewpoint of graduates and professors at a prestigious private Brazilian university.

We collected data from three main sources: questionnaires, interviews and non-participant observation (Jaccoud and Mayer, 2008) to avoid possible bias resulting from a single data source. Both researchers acted as participant observers during the research period, interacting with other professors and students and participating actively in changes promoted in the Master's Program.

In the analysis, the issues were clustered into three dimensions: academic, social and institutional. These dimensions were defined as the main general areas that best represent the overall academic context of colleges and universities, aligned with the core of the academic programs that are the focus of the study: academic program, students and faculty, and institutional perspectives.

Initially an online questionnaire applied electronically to former students was used. The purpose of the questionnaire was to identify the extent to which the Master's Program contributed to a graduate's professional practice. The perception of the former students was measured on an attitudinal Likert scale.

The population was composed of 86 former students who graduated between 2007 and 2010 . Of this group, 74 former students effectively participated in the study, resulting in a highly representative and valid sample. The gap is attributed to invalid, incomplete or non-responses.

Initially, an online questionnaire applied electronically to former students was used. The purpose of the questionnaire was to identify the extent to which the Academic Master's Program in question actually contributed to the graduates' professional practice. The population was made up of 86 former students who graduated between 2007 and 2010. Of this group, 74 former students effectively participated in the study, resulting in a highly representative and valid sample.

In the second stage, the reaction of seven professors to the perception of the students was obtained through in-depth interviews (Stake, 1994), resulting in a distinct perception that enriched the quality of the data and strengthened the analysis and results. The interviewees were asked to indicate to what degree they agreed or disagreed with the statements in the research instrument. The sampling criterion that we adopted for the interviews and the questionnaires was intentional, focusing on former students and professors of the same Master's Program. The data collection instruments were tested and validated with similar individuals from another Master's Program that did not participate in the study. The interviews and field diary were transcribed for analysis.

The perception of the former students was measured on an attitudinal Likert scale. The interviewees were asked to indicate to what degree they agreed or disagreed with the essence of the structured statements based on issues derived from the three dimensions: academic (Peterson et al., 1997; Gumport, 2000, 2007 and Bastedo, 2012), social (Meyer and Murphy, 2003; Datar et al., 
2010).), and institutional (Meyer and Rowan, 1978, 2006; Scott, 1995).

To prepare the instrument and data analysis, the elements presented in the Table 1, below, were considered and clustered into the aforementioned three dimensions.

Table 1. Research dimensions

\begin{tabular}{|c|c|c|}
\hline \multicolumn{3}{|c|}{ Research Dimensions } \\
\hline ACADEMIC & SOCIAL & INSTITUTIONAL \\
\hline $\begin{array}{l}\text { Most important } \\
\text { aspects in } \\
\text { academic } \\
\text { qualification of } \\
\text { graduates in the } \\
\text { Master's Degree } \\
\text { Program for } \\
\text { professional } \\
\text { practice. }\end{array}$ & $\begin{array}{l}\text { Factors that } \\
\text { influenced the } \\
\text { socialization } \\
\text { resulting from } \\
\text { the academic } \\
\text { experience of } \\
\text { the Master's } \\
\text { Degree } \\
\text { program in } \\
\text { management. }\end{array}$ & $\begin{array}{l}\text { Elements that } \\
\text { highlight the } \\
\text { importance of the } \\
\text { program and } \\
\text { institution to } \\
\text { professional } \\
\text { practice. }\end{array}$ \\
\hline \multicolumn{3}{|c|}{ Elements of Analysis } \\
\hline $\begin{array}{l}\text { Manager's } \\
\text { qualification; } \\
\text { Professor's } \\
\text { qualification } \\
\text { Researcher's } \\
\text { qualification }\end{array}$ & $\begin{array}{l}\text { Social networks } \\
\text { (formal and } \\
\text { informal); } \\
\text { Interaction with } \\
\text { environment; } \\
\text { Language; } \\
\text { Integration. }\end{array}$ & $\begin{array}{l}\text { Image; } \\
\text { Prestige; } \\
\text { Legitimacy. }\end{array}$ \\
\hline
\end{tabular}

Source: Research data.

The primary data were examined in the Narrative Analysis (Tsoukas and Hatch, 2001) focusing on the meaning as the analysis technique. The questionnaire data were analyzed using descriptive statistics, with the support of Microsoft Excel. The triangulation of data sources was sought in different types of strategies of gathering and analyzing the data.

\section{Analysis}

The challenge in this study was to analyze the data obtained from the graduates' perception of teaching in management, considering a complex and dynamic reality represented by management education, which is heavily influenced by economic, social, political and psychological factors, particularly regarding the program and professional market. Special attention was paid to the interface program and professional market, establishing under which conditions the three dimensions in question overlap with the diverse elements that exist in this context.

The professional profile of the graduates ind icated their main occupations after completing the Master's Degree program. The dat a revealed that only $43 \%$ work in management as their main activity, and $20 \%$ claimed that management was a secondary activity. We also found that $68 \%$ of the respondents work in teaching, either as their main activity $(27 \%)$ or as a secondary activity (41\%). We attribute the high number of graduates working in teaching to the fact that it provides them with a supplementary source of income.

In addition, the profile of the students pointed out that around $40 \%$ of the respondents work in consultancy as a main or secondary professional activity. Like teaching, consultancy serves to supplement their income. Finally, it is important to emphasize the number of graduates not working in management (around 30\%). Possible reasons for this are the economic situation of the country, the dynamic of the work market and transitions, and a gap between students' skills and knowledge vis-avis market demands and expectations.

In the last decade management education has been the target of criticism that has generated tensions in business sc hools, and particularly Academic Master's programs in Management. To respond to new demands, changes are required, focusing on the curriculum $\mathrm{s}$ tructure, teaching methods, social integration and better alignment with the labor market and the community's expectations. By examining the reality of a particular Academic Master's program, from academic, social and institutional perspectives (lens), critical points arise that will challenge those in charge of the management education program that is the focus of this study.

\subsection{Academic dimension}


Regarding the academic dimension, our study examined elements such as program structure, curriculum, training, qualification and prestige of professors, teaching and teaching method, preparation for research and the adaptation of professional training to the reality of the market in terms of developing the required skills and capabilities.

Figure 1. Academic dimension: influential factors

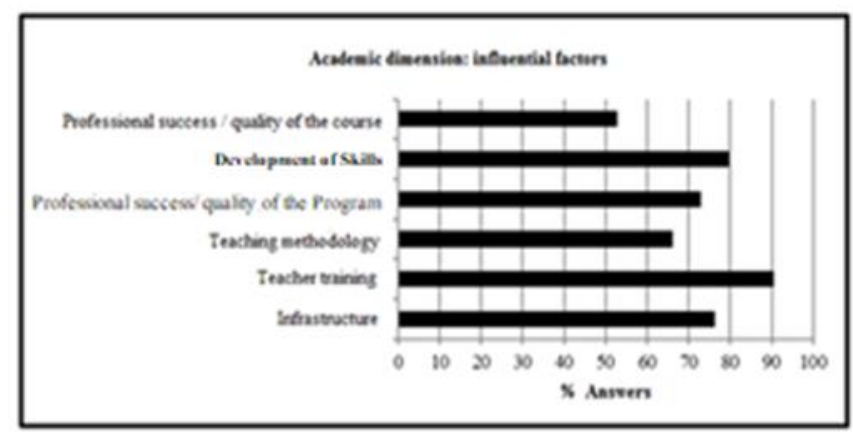

Source: Research data.

We found that approximately $75 \%$ of the sample consider the program structure satisfactory in terms of physical space, study environment, laboratories and software. However, these respondents believe that the library does not yet meet the standard of quality required for a Master's program, although the students have used the CAPES Journals Portal - an electronic database of national and international journals in diverse fields of knowledge and study.

Over $90 \%$ of the respondents felt that the professors are adequately qualified to conduct classroom activities. The prestige of the teaching staff was a key factor in their choice of coursework. An interesting point is that the teaching method was highlighted as positive, but in the respondents' view the teaching did not spur them to expand their knowledge, which resulted in a feeling of frustration (Figure 2). This was the first inconsistency found in the responses. Although the two concepts had features that distinguished them, the teaching method and the teaching itself were closely related.

The respondents believed that the program developed skills that meet the requirements of the job market (72\%). However, it was interesting that a significant part $(30 \%)$ of the sample is not working in management, as mentioned above, and that the teaching was highly theoretical.

Training for research was considered a strong point of the program by the vast majority of the respondents $(80 \%)$. The importance of this feature may be due to the requirement to present a dissertation as the main requisite for and obstacle to gaining the Master's Degree. Without research and a defense of its results, the Master's Program cannot be concluded.

Another point regarding preparation for research that we must stress is that it should not always be viewed as positive. On the contrary, curricula emphasizing abstract scientific models over evaluation based on practical skills have been heavily criticized by authors such as Pfeffer and Fong (2002), Elmuti (2004), Bennis and O'Toole (2005) and Podolny (2009).

Around half of the respondents (52\%) credit their professional success to the quality of the training in the Master's program. However, once again, we should highlight the considerable number of respondents that are not working in the field of management.

Some limitations and criticisms of the program were identified, as shown in Figure 2.

Figure 2. Academic dimension: critical factors

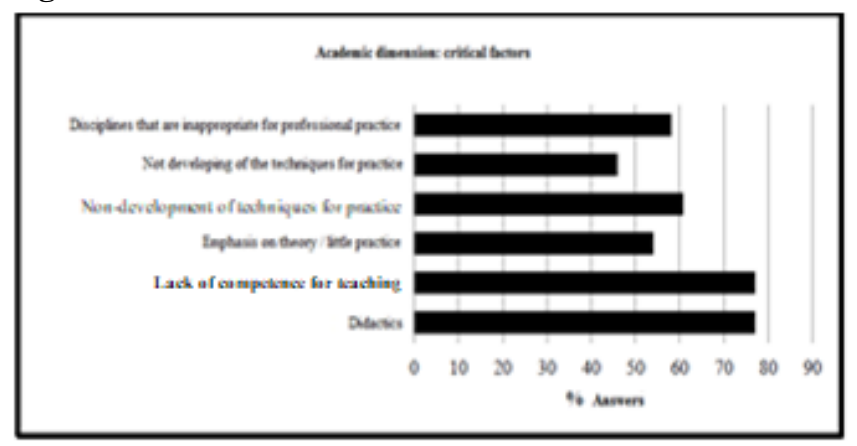

Source: Research data.

The most frequently voiced criticisms that deserve to be highlighted focused on the program curriculum. Although an impressive number of respondents believed that the program helped to develop useful skills for the work market, paradoxically, almost $60 \%$ concluded that the disciplines were not aligned with professional practice.

The program was considered essentially theoretical, with little practical content, by $55 \%$ of the respondents, and as not 
developing adequate mastery of the techniques req uired for professional practice $(45 \%)$. Consequentl $\mathrm{y}$, it did not provide the students with the managerial skills they desired. This finding corroborates the $\mathrm{c}$ riticisms made by Pfeffer and Fong (2002), Mintzberg (2004), Bennis and O'Toole (2005), Ghoshal (2005) and Grey (2004; 2009). To these authors, an executive cannot be taught how to act in the work market in formal education, and will only learn by gaining experience.

In our opinion, it is a cause for concern that $40 \%$ of the respondents concluded that the program did not help to define their field in the market. Despite highlighting that the progra $\mathrm{m}$ was predominantly theoretical in nature, $77 \%$ of the respondents felt that critical spirit, based on theories, was not strongly developed.

This criticism deserves attention because the teaching of management needs to go beyond the simple prescription of models, approaches and tools, also focusing on the limits of these approaches, theories and the ideology on which they are built, which appears not to have been the case in this study. The time has come to rebalance the curriculum away from excessive theory and place more emphasis on managerial skills and social aspects of the profession that are now demanded by the labor market and society.

Again, the graduates echo the criticisms of researchers, who warned of the negative influence of theories on business management taught in schools. The exaggerated emphasis on rationalism and utilitarianism, and the neglect of political, social, ethical and psychological aspects in organizational practice, are among the strong arguments used in the debate (Parker, 2002; Pfeffer \& Fong, 2002; Ghoshal, 2005; Bennis and O'Toole, 2005; Grey, 2004; 2009).

One of the aims of the Master's program in management, like all other academic Master's and Doctorate programs accredited by the Ministry of Education - CAPES, is to train professors, which is the reason why the graduates were asked about the development of skills required for teaching.

What we found is that over $60 \%$ of the respondents concluded that they were not prepared for teaching. We recall that even the teaching by the program's professors was a source of frustration for $76 \%$ of the respondents. This negative evaluation is especially worrying when we see that the vast majority of graduates $(68 \%)$ list teaching as their primary or secondary professional activity, even though they do not feel that they were adequately prepared for it.

The professors that were interviewed reacted to the criticisms of the students. Regarding teacher training, the vast majority of the interviewees recognized that this is one of the goals of the Master's program. However, in the Master's program, they did not identify proposals that were intended to train teachers.

In this respect, one of the professors stated: "we did not train the professor, but we offered experiences that seek to provide a view of what constitutes a class" (Interviewee 3). To this interviewee, these experiences are offered at the seminars, an opportunity in which students are obliged to prepare themes with which they are not yet familiar and present them in the classroom.

Concerning the criticisms regarding excessive emphasis on theory and lack of professional practice, the professors provided a number of justifications for the proposals of the program. To Interviewee 1 “the Master's Program was projected to comply with the CAPES assessment system", which until the early 2000s favored the academic bias of this kind of program. Although the CAPES is now encouraging professional Master's programs that focus more on the market, Master's programs in Management continue to be judged by the production of scientific articles.

As one professor argued, the institution should separate the Master's and Doctoral programs more clearly, and highlighted that researchers should be trained through the doctorate program (Interviewee 1). This opinion was shared by Interviewee 4 , who understood that there is a certain amount of confusion, not only at the institution but in Brazil in general, regarding the difference between a Master's Degree and Doctorate. “Earning a Master's Degree means greater focus on the development of knowledge, of knowing rather than doing." (Interviewee 2)

However, Interviewee 3 recalled that the proposal of the program was idealized for the Master's Degree. It was intended to initiate students into scientific research and prepare them 
for academia. The professor remembered that Academic Master's programs differ from MBAs and Brazilian specializations. The Master's Program provides a critical viewpoint to students who are already in the market, helping to improve their activities. Although students are not specifically prepared for professional practice, this practice improves as a consequence of the themes that are discussed in the classroom. (Interviewee $3)$.

The proposal of the Academic Master's program was defined by Interviewees 5 and 7 with the argument that executives have a short-term view. They almost always seek immediate results, and therefore, they need skills that allow them to survive the everyday life of the company. Researchers, however, are trained to find long-term solutions to organizational management challenges.

Another professor also highlighted that the Program should offer new forms of thinking and acting and that students should be trained for functions that do not yet exist in the market. The forms of management that we know are constantly changing and the skills required today will be of little use in the near future (Interviewee 7).

Professors and students agree that the teacher training is not adapted to the reality of the market. This is a cause for concern because the vast majority of students on the Master's program work in teaching as their second principal professional activity.

There is clearly a weak distinction between Academic Master's and Doctoral programs in the statements of the professors. This stems from the origin of graduate programs in Brazil, when the system was fundamentally centered on Master's programs with academic characteristics. In these new times, a more proactive attitude is being demanded of graduate programs in management in Brazil.

The emphasis on essentially theoretical content pointed out by the students was defended by most of the professors, who argued that academic training promotes the critical thinking required for a long-term view, and that this was not perceived by the students. This contrasts with the constant changes in the job market regarding managerial skills and capabilities in organizations.

\subsection{Social dimension}

In the social dimension, we looked at issues such as the formation of social networks, interaction with the environment and the development of the language used in the practice of management as possible facilitating factors for entry and growth in the professional market. The research was based on the premise that the program environment enabled the formation of social networks and that these had somehow aided inclusion in the job market. The respondents found it difficult to decide on their positions in this respect, as $36 \%$ marked the uncertain option, while $44 \%$ disagreed with the statement and only $20 \%$ agreed with it (Figure 3).

On the other hand, most of the sample (62\%) indicated that the individualistic behavior of the students hindered socialization in the group, which may be a factor that impedes the formation of informal social networks, and even the integration of the group. This has implications for professional practice, as teams or work groups are constantly organized and reorganized according to the needs and dynamic of the organization.

Regarding another aspect of the social dimension, only $42 \%$ of the respondents agreed that the jargon used in the work market was disseminated during the program. This response is surprising, as it appears impossible that a Master's program in management, as in any other professional field, would not adopt the technical language used in books and articles on the diverse range of aspects of management in organizations, as the language is of great importance to the market in which the professionals operate (Grey, 2004; 2009). We believe that the statement on language was not sufficiently understood by the graduates.

Most of the professors that were interviewed agreed that the Master's program does not favor the formation of networks. However, they pointed out a diversity of factors to account for this. According to Interviewee 1, this occurs due to the students' profile. Students do what they can to avoid being physically present, as they work and have numerous other commitments.

However, according to Interviewees 3 and 4, one of the shortcomings of the program is that it does not offer opportunities for socialization. In their opinion, the program should encourage students to socialize. They noted that when 
networks exist, they are formed spontaneously and informally.

"I think we have really got this wrong... we do very little... after students get their credits... it becomes an individual work with the supervisor... we don't have mechanisms that encourage socializing... we should rethink this" (Interviewee 3)

As for the development of adequate technical language in the training process, it was highlighted that professors have their own jargon related to their professional areas and their themes of research and use this vocabulary intensely in the classroom. This enables students to acquire a language that is adequate for the business environment through assimilation (Interviewee 7).

It is interesting that the students were not aware of the fact that the disciplines of the Master's program disseminated approaches, symbols and the languages that integrate the jargon of management.

As a result, the socialization of the Master's students was considered weak by both graduates and professors. This deficiency resulted from a restricted flow of information that is important in terms of the job market, salaries and employability.

Figure 3. Social dimension

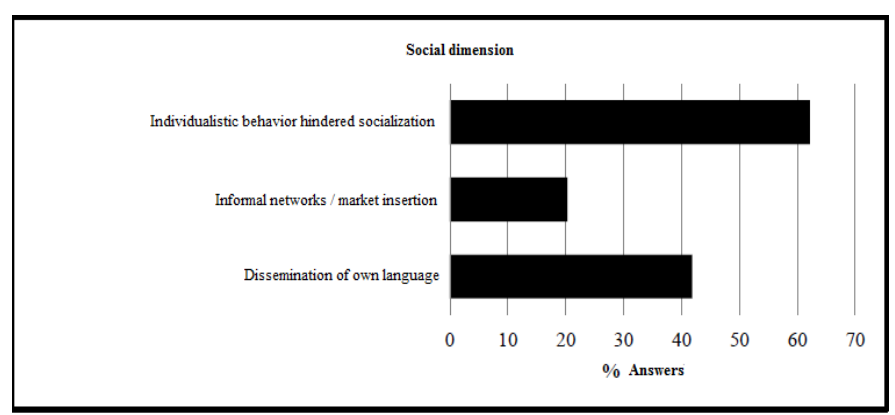

Source: Research data.

\subsection{Institutional dimension}

In the institutional dimension, our study looked at issues such as the importance of the concept of the Master's program in the eyes of the CAPES, the prestige of the institution and the requirement of the diploma to enter the work market.

On the subject of the diploma being required by employers, only $30 \%$ of the respondents agreed that the diploma, as a credential, was needed to enter the work market. The same number of respondents, in answer to a previous question, had already said that the fact that the market did not show a preference for graduates made it harder for them to find work. These conclusions contradict the literature, especially what Collins (1979) and Berg (2003) call the credentialist society, meaning a society that demands diplomas for professional practice. According to the graduates who participated in the study, the business world does not value educational credentials in the case of the professional management market.

Figure 4. Institutional dimension

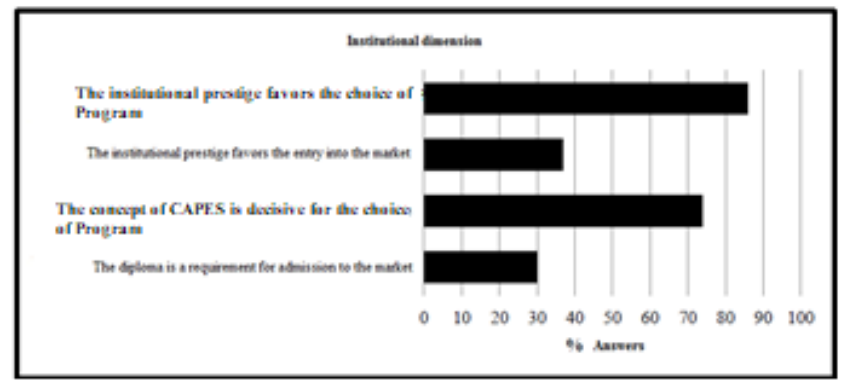

Source: Research data.

However, when asked about teaching, the situation was different. Management schools, due to legal requirements, need to hire professors with at least a Master's Degree, preferably a Doctorate. Thus, as a positive evaluation in the ranking of the Ministry of Education-CAPES is required for programs to be accredited and, consequently, for diplomas to be validated. The graduates took this into account when choosing the program (74\%) and the institution where they would enroll for their Master's Degree (86\%). It is also important to mention that the institution in question is a private university that charges fees for its tuition and services, whereas in public universities similar programs are tuition free.

The prestige of the institution, on the other hand, proved not to be influential. According to the respondents, this factor was not decisive when it came to entering the work market, emphasizing the notion that the business world in Brazil is not credentialist in nature.

When discussing the institutional dimension, most of the professors highlighted the strength of the university's brand. However, some agreed that the institution should exploit the strength of its brand better, including through partnerships with the business sector. These partnerships would be 
yet another factor to attract new students (Interviewees 1, 2 and 4).

Some professors also highlighted the flexibility of the Master's program as an element for attracting students, especially those already in the work market who cannot dedicate themselves full time to academic activities (Interviewees 2 and $3)$. The fact that the institution is private and charges tuition was also highlighted by the professors. The financial issue restricts the attraction of the program

Regarding the CAPES evaluation, some professors seemed to agree that the concept of the program is not the decisive element, neither for students that choose the program, nor for the market that selects graduates (Interviewees 1 and 4).

\begin{abstract}
"Having a concept of 3, 4, 5, 6 or 7 at the CAPES doesn't make any difference ... because employers don't know the difference between concept 3 and 7 , but they know the difference between our institution and other private institutions in the region" (Interviewee 1)
\end{abstract}

On the other hand, with their opinions differing from those of the graduates, the professors argued that a diploma from a prestigious institution could be decisive when it comes to entering the market. The importance of the institutional brand was highlighted by students and professors. To the former, the institutional brand was attractive, but not decisive when entering the job market. To the professors, the institution should exploit the brand name more with regard to the market, particularly the business sector. A possible effect of partnerships with the business community would be the placement of more graduates in the world of work.

\section{Discussion}

Measuring the performance of academic Master's programs in management in Brazil using criteria other than those set by the CAPES has been necessary for a long time. We believe that the study of academic, social and institutional dimensions makes a contribution by examining critical aspects of this type of education in the field of management. This is of great importance, first because it involves elements not included in the formal evaluation and, second, because of the discourse that this form of education is transformative and is of great benefit to professional practice, especially in terms of careers and salaries.

In academia, we saw that the Master's program is strategically oriented to meet the requirements of the CAPES rather than the expectations or demands of the production sector or its users. This leads to isomorphism of goals, structuration behavior and standards of quality, resulting in graduates with very similar professional profiles. Furthermore, the work market for management does not favor credentials such as a Master's Degree.

The main consequences of this are a widening gap between essentially academic training, the requirement of the work market and the employability of graduates from this type of program. On the other hand, the diploma is more important in the higher education market, where certificates are required and where the differential for the graduate is the prestige of the certification institution.

Three major problems in management education pose a challenge to business schools, and Master's programs in particular. The first is the difficulty involved in teaching managerial practices in the classroom (Mintzberg, 2004; Grey, 2009). The second is the discrepancy between the curriculum taught and the skills required in the work market (Pfeffer and Fong, 2002; Bennis and O'Toole, 2005). The third is the gap between dissertations and theses, and the reality of the market (Ghoshal, 2005; Antonacopoulou, 2010). The focus of the vast majority of studies is on academic and research interests, particularly in the tutors' fields of study. This is an unsuitable practice for professional qualification programs, as is the case of Master's programs in management (Bennis and O'Toole, 2005; Grey, 2004; 2009).

If teaching has an appeal in the market to graduates, as the data indicated in the academic dimension, more attention ought to be paid within the Master's program to courses and seminars on teaching skills, in addition to greater participation of students in the classroom as teaching assistants under the supervision of the faculty.

Education is known to result in individual and social benefits for students (Bowen, 1991; Meyer and Lopes, 2015) and a public good that 
provides public benefits (Tierney, 2006). This is true not only in professional education, but in higher education in general, as it aids intellectual, emotional and human development, reinforcing the relevance of the social dimension of this study. A typical professional education process involves knowledge, mastery of language and use of specific rational and utilitarian tools. However, this education comprises a set of subjects of a humanistic, social, political, ethical and psychological nature that complement professional education, providing students with broader horizons richer than anything that occurs in real life organizations and the world outside academia (Parker, 2002; Gosling and Mintzberg, 2006; Grey, 2009; Ordine, 2013).

What is taught, how it is taught and how this knowledge is transferred to professional life constitutes a challenge for Master's programs in management (Pearce, 2007). Likewise, we hope the limits of the theoretical approaches and diverse ideologies in which these theories and techniques are embedded will be exposed, revealing the false neutrality that is often attributed to them (Elmuti, 2004).

In the case in question, the graduates voiced their frustration with the teaching in the classroom, which can be better understood through the methodological model used by the professors. The teaching, a pivotal function in the academic dimension of this study, tends to be overlooked, with priority given to publishing articles in refereed journals, which is highly valued in CAPES evaluations.

As identified in the Master's program in question, the predominant methodology used in the courses followed a seminar format with strong emphasis on reading and discussing scientific articles and book chapters. Far removed from professional practice, many of the theories presented end up compromising the knowledge gained by the students and destroying good practices in the market, as stressed by Ghoshal (2005) and Pearce (2007).

When it comes to training for research, the graduates were clearly satisfied with the result, corroborating the findings of Bennis and O'Toole (2005) that management schools confer respectability on scientific research and eliminate vocational stigma. The study shows that even the teaching method used in the courses for research was viewed in a positive light. These courses help to shape articles for the finalization of other courses and for publication in periodicals and, most importantly, provide tools for the dissertation required for certification.

Master's programs in management, like other academic programs, are known to follow a culture of maintaining the status quo, with little room for initiatives of innovation and change. Internally, we can attribute this resistance to change to the conservative nature of professors, who seek to maintain current conditions. Nowadays, innovation and creativity are critical factors in the current dynamic and competitive world, especially in business. They need to be analyzed in practical terms in programs focusing on organizational experiences. Externally, the evaluation policies of the regulating agency have a strong influence on the programs, focusing more on academic interests than the market.

We observed that socialization throughout the program was not relevant in the eyes of the graduates, with little impact on professional practice. The students did not build a social network to serve as a strategic link among them following graduation. Indeed, the graduates were not even capable of identifying a common language disseminated during the program.

The graduates' perceptions reveal that the program did not develop a social identity in the group. The situation can be justified by the fact that the program in question does not pay special attention to the relationships of students in and out of the classroom, but rather places greater emphasis on training for research.

Socialization among students during the program occurred in isolation, with no greater contribution towards placement in the work market. This is a cause for concern because an exchange of experiences has been identified as the main benefit of interacting with classmates (Wood Jr. and Cruz, 2014). Socialization derives from two essential characteristics of the program: the prior professional and life experience of students and diversity of profiles. It is associated with creating networks, and has a positive impact on changing jobs and advancing careers.

Researchers tend to underestimate the benefits of contacts and social networks related to 
employment and the labor market, including their positive or negative effects or even no effect at all (Caplan, 2018). This is particularly true in the case of professional schools like business schools. In fact, students quite often do informally exchange information about job opportunities and salaries in the market. Thus, discussions on social networks in business schools are important to students, particularly when incentives are provided by offering seminars about market conditions, jobs, career, salaries and employment during the Master's program.

Regarding the institutional dimension, the graduates recognized that the program`s reputation based on the CAPES evaluation was taken into consideration. In other words, they chose a program recognized for its quality and offered by an institution that enjoyed a good reputation. Moreover, they also agreed to pay for the services offered by the university, hoping that the diploma would lead to a quick entry into the job market and give them a curricular differential to improve their careers. However, according to the student's perceptions, these hopes were not fulfilled. These conclusions deserve a more detailed analysis, as we observed that almost two thirds of the respondents were professors in higher education, which they would not be without their Master's Degree diploma.

Despite the fact that this study concentrated in a single case, the similarities between Academic Master's programs in management, their role, structure, functioning and performance evaluation make it possible to extend some of the findings to the context of other Academic Master's programs in the country.

There is no evidence in this study to show that the Academic Master's program in management actually makes a significant contribution of the graduates' professional practice. However, the results led us to reflect on the importance of the academic, social and institutional dimensions when rethinking and improving an academic program in management, and its relationship with professional practices and the business world is of great importance. Therefore, there is no doubt that a gap remains to be bridged.

All these dimensions, however internal in nature, revealed critical points to be observed: for instance, in the academic dimension, the way the curriculum is structured and how management is taught in the classroom, and the limitations of business programs in preparing graduates for the business world, especially in terms of teaching methods and knowledge and skills required for the labor market. A huge gap prevails, leading to frustration not only for graduates seeking a position in the job market but also for employers whose needs are not met.

Providing incentives for students to socialize is another challenge to Academic Master's programs. By exposing students outside the classroom to new experiences would make them more familiar with the outside world. This would help to bridge the gap between academic management education and the outside world, where dynamic economic, social, political and technological forces prevail, setting the tone of business.

Thus, efforts in this area would seek to integrate students through initiatives that bring them closer to the outside reality of organizations whether in the private, public or nonprofit sector. Such initiatives would create an interface between the capabilities and knowledge of academia, allowing a closer look at the problems and challenges faced by those in charge of managing organizations in the productive sector.

The institutional role, whether of a university or academic program, is equally relevant, especially in terms of image, prestige, legitimacy and trust within the community. Beyond that, well developed strategies aiming to attract and retain students in times of fierce competition, based on tuition policies and student aid programs, would aid the better selectivity of students as well as the quality of education.

It is also imperative to think about the paths trodden by education management, and to learn to address ambiguities, paradoxes and uncertainties that are very much present and disseminated in organizational life and society at large, posing a challenge to managers.

This ambiguity has to do with the interpretation of reality in different dimensions, both utilitarian and humanist. In the case of management education, we have to consider that the success of students is related to individual, social, economic, technological and political 
variables, all of which are closely related. The way we respond to these challenges will lead us to different stances regarding which directions to follow and what decisions to make in order to rethink Academic Master's programs and promote the required changes in our education management training programs.

\section{Concluding Remarks}

The Academic Master's program in Management seems to be at a crossroads between following obsolete goals and ineffective academic practices. This is far from the reality of the productive sector, meaning that it is time to make changes and redesign teaching, learning and research processes to align the program with the conditions and demands of the job market. Today's structure and functioning reveal imperfections, incompleteness and inadequacies. However, as the number of these programs in management in Brazil is quite large, it is time to rethink the role of these Academic Master's programs and the conditions in which they operate. In this regard, the perception of the main players, the graduates, can contribute to the improvement of educational practices by reviewing or even substituting them. In addition, the reaction of faculty members makes a contribution by reinforcing that changes are needed. All of them have the potential to enhance the quality, relevance and benefits of academic programs in management for their stakeholders.

Therefore, the result of this study is important for professors, academic managers and students of academic Masters programs in management, where knowledge, skills and values are critical elements for the qualification of students and a factor valued by the productive sector and society. In a changing world, it is time for those individuals and groups with the responsibility of supervising graduate programs in Management to establish policies and guidelines to meet the demands of the market and expectations of society.

The challenges posed by the context require Master's programs in management to review the profile of the students that they wish to attract and train. This means updating the curriculum and teaching of management. It is imperative to align the expectations and needs of individuals, organizations, society and government, reducing tensions over the discrepancy between the skills and capabilities that are in demand and the professionals being placed in the market today. The humanistic side of training cannot be neglected by Master's programs in management.

In addition to the professional and utilitarian goal, it is also important to highlight the social factor, as organizations are essentially human, and management is work that requires the cooperation of people, led by managers. In this task we have, on the one hand, the aspect of productivity and efficiency and, on the other, the humanist content of values and principles, which is equally useful (Ordine,2013) and equally important for the functioning of organizations and life in society. Thus, much of what is considered useless makes an important contribution to the education of managers.

We need multiple knowledge, through numerous theoretical lenses and numerous technologies, to understand better the complexity of organizations and their management. As pointed out by Santos (1988), we are living in a society that appreciates a science that simultaneously produces knowledge and ignorance, making "[...] a scientist a specialist ignoramus and a citizen a general ignoramus" (Santos, 1988, p. 55).

Few Brazilian researchers have conducted studies involving the perception of graduates and faculty, especially with regard to graduate programs. New avenues should be considered for further research. Here are some key questions that we identified that could be used to guide future endeavors by researchers in the field. Seeking answers to these questions should also be a concern for academic managers and people at the CAPES, the agency in charge of establishing the guidelines for Academic Master's programs in Management:

1) Should Academic Master's programs formally continue with their purpose of preparing scientists, professionals and teachers in the field of management while the external environment displays a different reality in terms of demands?

2) Would it be feasible to keep operating a costly and tuition driven Academic Master's program in Management that is far 
from the reality of the demands of the productive sector?

3) Do improvements in the academic area like curriculum and teaching methods, and research topics together with institutional efforts allow the Academic Master's program in Management to respond to new demands and get back on the right track?

4) Does it make sense to maintain an Academic Master's programs in Management while a growing number of professional Master's programs have arrived on the market with the purpose of linking theory and the practical aspects of the profession?

5) To what extent are the problems faced by the Academic Master's program in Management due to a lack of leadership, strategic vision and power, reinforcing amateur academic management and highlighting a paradox in a professional program? (Simon, 1967; Keller, 1983; Meyer, 2003)

6) Do Academic (Master's) programs in Management conduct systematic follow-up studies of their graduates? If so, how do these studies provide feedback and improve the functioning academic activities?

7) What has hindered Academic Master's programs in Management and the development of studies focusing on the knowledge, skills and values taught to their students and the demands of the labor market?

We hope that our study will arouse the interest of researchers and encourage them to study the theme, as few studies of this nature have been conducted in Brazil. We also hope that the results of future studies, supported by theories and critiques of business schools, can be used to improve the training of managers, not only by adding value to the professional profile of graduates, but also by improving professional practices, preparing better managers of academic programs, meeting the needs of business, government, non-profits and the community and fulfilling the mission of higher education institutions. All efforts, in different strands, following distinct mechanisms, are needed to understand better and improve the complex nature of educational work in Master's programs in Management and their interface with the environment. This will result in contributions toward building a theory of higher education.

\section{References}

Antonacopoulou, E. P. (2010). Making the Business School More "Critical": Reflexive Critique Based on Phronesis as a Foundation for Impact. British Journal of Management, 21, pp. 625.

Bastedo, M. N. (2012). The Organization of higher education: Managing colleges for a new era. Baltimore: The Johns Hopkins University Press.

Bennis, W. G.; \& O'Toole, J. (2005). How the Business Schools Lost Their Way. Harvard Business Review, v. 83, n. 5, p. 96-104.

Berg, I. (2003). Education and Jobs: the great training robbery. New York: Percheron.

Birnbaum, R. (1989) How Colleges Work: The Cybernetic of academic organization and leadersnip. San Francisco: Jossy-Bass.

Bowen, H. (1991). Investment in learning. San Francisco: Jossey-Bass.

Caplan, B. (2018). The case against education: why the education system is a waste of time and money. Princeton: Princeton University Press.

Collins, R. K. (1979) The Credential Society. New York: Academic Press.

Creswell, J. W. (2007). Qualitative inquiry \& research design: Choosing among five approaches. Los Angeles: Sage.

Datar, S.M., Garvin, D.A., \& Cullen, P.G. (2010) Rethinking the MBA: Business education at a crossroads. Boston: Harvard Business Review Press.

Davila, A. (2012). Building Legitimacy in Latin 
American Business Schools. In: LAEMOS, Axixi, Mexico.

Eisenhardt, K.M. (1989). Building theories from case study research. Academy of Management Review, 14, (4), p. 532-550.

Elmuti, D. (2004). Can management be taught? Management Decision, v. 41, p. 439-453.

Ghoshal, S. (2005). Bad Management Theories Are Destroying Good Management Practices. Academy of Management Learning \& Education, v. 4, n. 1, pp. 75-91.

Gosling, J., \& Mintzberg, H. (2006). Management education as if both matter. Management Learning, 37, pp. 419-428.

Grey, C. (2004) Reinventing business schools: The contribution of critical management education. Academy of Management Learning \& Education, v. 3, pp. $178-186$.

Grey, C. (2009). A very short fairly interesting and reasonably cheap book about studying organizations. London: Sage.

Gumport, P. J. (2000) Academic restructuring: organizational change and institutional imperatives. Higher Education, 39, 67-91.

Gumport, P. J. (2007). Sociology of higher education: Contributions and their contexts. Baltimore: The Johns Hopkins University Press.

Jaccoud, M., \& Mayer, R. A observação direta e a pesquisa qualitativa. In: POUPART, J. et al. A Pesquisa qualitativa. Enfoques epistemológicos e metodológicos. Petrópolis, RJ: Vozes, 2008.

Jarzabkowski, P., Giulietti, M., Oliveira, B., \& Amoo, N. (2013) We Don't Need No Education Or Do We? Management Education and Alumni Adoption of Strategy Tools. Journal of Management Inquiry, v. 22, n. 1, pp. 4-24.

Keller, G. (1983) Academic Strategy: The management revolution in American higher education. Baltimore: The Johns Hopkins University Press.
Leavitt, H. J. (1991). Socializing our MBAs: Total Immersion? Managed Cultures? Brainwashing? California Management Review, v. 33, n. 4, pp. 127-143.

Meyer, V.Jr. (2003) Novo contexto e as habilidades do administrador universitário. In V.Meyer Jr. \& J.P.Murphy Dinossauros, gazelas e tigres: Novas abordagens da administração universitária. Florianópolis, Insular, p. 178-205.

Meyer J., \& Rowan, B. (1978). The structure of educational organizations. In M.W.Meyer (Ed.) Environments and organizations (pp. 78-109)

Meyer,V. Jr.; Murphy, J.P. (Eds.) (2003). Novo contexto $\mathrm{e}$ as habilidades do administrador universitário, In: Meyer \& Murphy (orgs.) Dinossauros, gazelas \& tigres: novas abordagens da administração universitária. Florianópolis: Insular, p.173-205.

Meyer V. Jr. \& Lopes, M.C. (2015) Administrando o imensurável: Uma crítica às organizações academicas. Cadernos EBAPE,BR, 13, (1), 40-51. Mintzberg, H. (2004). Managers not MBAs. San Francisco: Berret-Koehler.

Ordine, N. A. (2013). A Utilidade do Inútil. Rio de Janeiro: Zahar.

Paixao, R.B. \& Souza, M.A.D. (2018) Impact of programs on competency career and income on management graduates, RAUSP Management Journal, 53,(3), 441-458.

Parker, M. (2002). Against Management. Cambridge: Polity.

Pearce, J. L. (2007). We are who we teach. Journal of Management Inquiry, v.16, pp. 104-110.

Pfeffer, J., \& Fong, C. T. (2002). The end of business schools? Less success than meets the eye. Academy of Management Learning \& Education, v. 1, n. 1, pp. 78-95.

Peterson, M. W., Dill, D., \& Mets. L.A. (Eds.). (1997). Planning and management for a changing environment. San Francisco:Jossey-Bass. 
Podolny, J. M. (2009). The Buck Stops (and Starts) at Business School. Harvard Business Review, June, v. 87, pp. 62-67.

Santos, B. S. (1988). Um Discurso sobre as Ciências, Porto: Editora Afrontamento.

Scott, W.R. (1995). Institutions and organizations. Thousand Oaks, CA: Sage.

Simon, H. (1967) "The Job of a college president." Educational Record, 58, 68-78.

Stake, R. E. (1994) Case Studies. In: N. K. Denzin; Y. S. Lincoln (Eds.). Handbook of qualitative research. London: Sage. pp. 236-247.

Tierney, W. (2006). Trust and the public good: examining the cultural conditions of academic work. New York: Peter Lang.

Tsoukas, H. \& Hatch, M.J. (2001) Complex thinking, complex practice: The case of narrative approach to organizational complexity. Human Relations, 54,(8), p. 979-1013

Wood JR., T., \& CRUZ, J. F. P. (2014). MBAs: cinco discursos em busca de uma nova narrativa. Cadernos Ebape, v. 12, n. 1 jan./mar., pp.26-44. 